\title{
Comments on "Recommendations of the Brazilian Society of Rheumatology for the diagnosis and treatment of Chikungunya fever. Part 2 - Treatment"
}

\section{Vinod Ravindran}

I have read with interest "Recommendations of the Brazilian Society of Rheumatology for the diagnosis and treatment of Chikungunya fever. Part 2 - Treatment" [1]. This is an important document and among the first from a national society on a disease with tremendous global burden.

However, I am disappointed with the inadvertent inaccuracies in the presentation and interpretation of our study [2] in the above-mentioned guidelines and hence I would like to hightlight those mistakes and point out the correct information.

Statements and comments from the recommendations [1] include;

"It should be noted that the sample of this study was small."

"Ravindran et al. conducted an uncontrolled, open study that included patients with more than 1 year of arthritis post-infection with CHIKV who failed to respond to the use of HCQ alone."

"Another uncontrolled study ...".

"The study by Ravindran et al. showed good response in only $12.5 \%$ of 16 patients who used SSZ as monotherapy in the chronic phase of Chikungunya fever. When combined with MTX, the response increased to $71.4 \%$. It should be noted that all cases included had already used HCQ (200 mg/day) and NSAIDs."

We had conducted a 24 weeks, randomized, and controlled open label study to appraise the efficacy of a combination of disease modifying antirheumatic drugs (DMARDs) regimen compared to hydroxychloquine (HCQ) monotherapy in patients with persistent arthritis post-infection with CHIKV [2]. All the patients with persistent arthritis were on HCQ and were randomized

Correspondence: drvinod12@gmail.com

Centre for Rheumatology, Calicut, Kerala, India either to continue HCQ monotherapy or receive a fixed-dose combination therapy with methotrexate (MTX) $15 \mathrm{mg} /$ week, sulfasalazine (SSZ) $1 \mathrm{~g} /$ day, and HCQ $400 \mathrm{mg} /$ day.

Our study was reported according to the CONSORT guidelines. The sample size calculation was performed to provide $80 \%$ power at $5 \%$ significance level assuming a dropout rate of $10 \%$ and estimated 35 patients per group. In our study all patients in the DMARDs group received SSZ at fixed dose. None of the patients in either group received SSZ as monotherapy or MTX as an add-on to SSZ therapy.

The erroneous report undermines the quality and validity of our work. These clarifications provide better understanding about our important contribution on this issue.

\section{Abbreviations}

CHIKV: Chikungunya virus; DMARDS: Disease-modifying antirheumatic drugs; HCQ: Hydroxychloroquine; MTX: Methotrexate; NSAIDs: Non-steroidal antiinflammatory drugs; SSZ: Sulfasalazine

\section{Author's contributions}

VR is the sole author of the manuscript. The author read and approved the final manuscript

Ethics approval and consent to participate Not applicable.

\section{Consent for publication}

Not applicable.

\section{Competing interests}

The authors declare that they have no competing interest.

\section{Publisher's Note}

Springer Nature remains neutral with regard to jurisdictional claims in published maps and institutional affiliations. 
Received: 7 August 2018 Accepted: 9 August 2018

Published online: 12 September 2018

\section{References}

1. Marques CDL, et al. Recommendations of the Brazilian Society of

Rheumatology for the diagnosis and treatment of chikungunya fever.

Part 2 - Treatment. Rev Bras Reumatol Engl Ed. 2017;57(Suppl 2):438-51. https://doi.org/10.1016/j.rbre.2017.06.004.

2. Ravindran V, Alias G. Efficacy of combination DMARD therapy vs. hydroxychloroquine monotherapy in chronic persistent chikungunya arthritis: a 24-week randomized controlled open label study. Clin Rheumatol. 2017 Jun;36(6):1335-40. https://doi.org/10.1007/s10067016-3429-0.

- fast, convenient online submission

- thorough peer review by experienced researchers in your field

- rapid publication on acceptance

- support for research data, including large and complex data types

- gold Open Access which fosters wider collaboration and increased citations

- maximum visibility for your research: over $100 \mathrm{M}$ website views per year

At BMC, research is always in progress.

Learn more biomedcentral.com/submissions 